\title{
IMAGINATIVE EXPERIENCE A Narrative-Dialogic Ethnography of the Community Who Adores Its Idol
}

\begin{abstract}
EkaArdianto
Managing customer loyalty becomes an important activity in marketing management. One of the reasons is that loyal consumers tend to make good financial performances to producer. Unfortunately, gaining a loyal customer is not a trivial activity since there are gaps to understand consumer experience comprehensively. To fulfill the gaps, this article explores imaginative experience of the community who adores its idol in the light of cultural perspective. The members of the community who adores its idol experience the imaginative experience. The author argues that those phenomena are cultural perspective, because they are meaningful to the members. Through narrative-dialogic ethnography, the author builds the concept of imaginative experience that through the imaginative media, the members do narrative-dialogic between "the realm of areal" and "the realm of afotik" then activate the imaginative relations in "the realm of aktinik". Every member constructs its imaginative relations into imaginative constructions formed in a personal story. Managing imaginative experience could benefit the company. It can be the "Imaginative Experience Management" (IEM) that accommodates imaginative consumers' experiences with the company's products deeply and sustainably through managing the story of its consumers' imaginative experiences. It can also be linked to the customer loyalty programs. In this matter, IEM should be integrated with brand management.
\end{abstract}

Keywords: community; consumer behavior; customer loyalty; consumer experience; imaginative; idol; culture; ethnography 


\section{Introduction}

One of the major tasks of every brand manager is to understand more closely how consumer experiences its products (Schmitt 1999). Furthermore, Holbrook (2000) argues that experiential perspective is one of the millennial consumers in the texts of our times. Furthermore, consumer experiences should be viewed in cultural perspective (Spradley and Mc Curdy 1975). From that view, loyal customers tend to relate to cultural experiences, because of a status symbol, and it is meaningful (Kelly 1987).

This paper explores imaginative experience of the community who adores its idol through a narrativedialogic ethnography. In brand management literature, the brand image is one of 'the sacred assets' that should be managed seriously (Keller 2003), but there are gaps to understand closely how consumers experience their product imaginatively. Moreover, ethnography is effectively used when fresh insights are desired about consumerrelated behavior (Mariampolski 2006). Therefore, the objective of this paper is to build the concept of imaginative experiencethrough a narrative-dialogic ethnography.

\section{The Concept of Idol}

In consumer behavior literature, there are close definitions of the concept of idol. First, the concept of vicarious learning that refers to process by which people change their behaviors because they observed the actions of other people and the consequences that occurred. In general, people tend to imitate the behavior of others when they see that it leads to positive consequences, and they tend to avoid performing the behavior of others when they see that it leads to negative consequences. Vicarious learning is also called modeling. Overt modeling involves consumers who are actually observing the model (Peter and Olson 2002). Secondly, the concept of reference group that involves one or more people that someone uses for a basis for comparison or point of reference or frames of reference in forming affective and cognitive responses and performing behaviors. Reference groups can be of any size (from one person to hundreds of people) and may be tangible (actual people) or intangible and symbolic (successful business executives or sports heroes) (Peter and Olson 2002; Schiffman and Kanuk 2006). There are three types of reference groups can be described: aspirational, associative, and dissociative. Aspirational reference groups are groups that we admire and wish to be like but are not currently a member of. Associative reference groups are groups that we do belong to. Dissociative reference groups are groups whose attitudes, values and behaviors we disapprove of and that we do not wish to emulate (Hoyer and MacInnis 1997).

Those concepts relate to how the model become a frame of reference and could influence its consumers to do something, but there is still a gap how the model could influence to its 
consumers to activate its imaginative experience.

\section{The Concept of Imagination}

In some consumer behavior literature, several authors state the concept of imaginative or imaginations or imaginary. Stevens and MacLaran (2005), who study how women's magazines function as 'dream worlds' of shopping and how contemporary readers consume these imaginary shopping spaces, define imagination as a visual stimulation derived from 'consumer gaze' that blurs the boundary between fantasy and reality. Martin (2004) focused on a thematizing of the fantastic imaginary. The term thematizing refers to how the evoked imaginary is given form as mental imagery that involves quasi-pictorial representation. Martin argues that fantastic imaginary refers to the imaginary that is evoked and thematized in a fantastic context. Besides that, Molesworth (2006) argues that the aspects of reality used to evoke the imaginary may vary, but they may also include brands as ideas that we are used to daydreaming about. Brands may therefore 'connect' fantasies to individuals' everyday experiences. Chronis (2005) argues that the state of "what it really was like" may take the form of a mental picture or an imaginary narrative vignette that depicts a specific slice of life in the past.

Those concepts, on one side, are blurred between the concept of imagination and fantasy, on the other side they focus on the past phenomena. Even though it reveals the representation of image, there is still a gap to understand how imagination can relate to the consumers - particularly the fans- and its idol. Different from those concepts of imagination, I consider the concept of imagination derived from Casey (1991). It is the phenomenological point of view, that the definition of imagination is related to intentional structure. Intentional refers to consciousness, that the internal experience of being conscious of something; thus the act of consciousness and the object of consciousness are intentionally related (Moustakas 1994). In short, imagination is a relational concept, between the subject (as an imaginer) and the object (as an image). Furthermore, Casey states that structure of imagination can be regarded into an act of imagining and an object imagined. For Casey, imagination is a creative activity in contrast to a fantasy.

"Fantasy is mere nonsense, afleeting impression; but imagination is active, purposeful creation...Afantasy is more or less your own invention, and remains on the surface of personal things and conscious expectations. But active imagination, as term denotes, means that the images have a life of their own and that the symbolic events develop according to their own logic" (Casey 1991:4).

More over Casey argues that:

"I construe the term "image" not in its usual meaning -i.e., as a 
Gadjah Mada International Journal of Business, September - December 2007, Vol. 9, No. 3

pictorial form of imaginative presentation-but rather as the mode of presentation with which imagined content is given to the imaginer's consciousness. The image is not what is present to awareness -this is the content proper-but how this content is presented "(Casey 1991:39, original emphasis) because in imagination, a "leap" between two wholly disparate states can occur, indeterminacy and possibility consequently are the characteristics of the image" (Casey 1991: 42).

Creative activity in imagination happens both in the structure of subject-object imagined; it is the subject dominated (because the subject has motivation and intention) and the object dominated (because one image lives and can appear synthetically with another image). The former is imagining, and the latter is imaging (Casey 1991). Imaging is not only how certain object looks but also how it might feel to the touch. By specifically sensory, as characterized by predicates that specify whether the imagined object is visualized, audialized, smelled in the mind's nose, or felt in the mind's muscles. He gives us an example of imagining and imaging when we imagine that a speeding car is running us down. In that imagination we can also entertain whole complexes of simultaneously apprehend entities-what he shall call states of affairs. From those Casey arguments, I consider that both imagining and imaging cannot be separated in the imagination. For that rea- son, in this paper, imagination contains both imagining and imaging.

\section{The Concept of Experience}

Holbrook and Hirschman (1982) in their monumental paper argue that fantasies, feelings, and fun as the "experiential view". Since then, there are various studies in the area of experience. For instance, Carù and Cova (2006) developed a more detailed approach to the process of immersion in a consumption experience using the notion of operations of appropriation. Besides that, Moisio and Arnould (2005) studied the extended dramaturgical framework incorporates distinctions between drama structure, drama interaction, and drama content and offers marketing researchers and managers a more comprehensive understanding of the ways in which cultural resources, active consumer agency and formal components of shopping performances contribute to shopping experiences. Others authors, Chan and McNeal (2006), argue that shopping experience increased significantly among older children, apparently those who have some knowledge of products and some money to spend on them (as compared to the younger children).

Those concepts relate to how consumers feel their experience, but the gap of "what experience is" still remains. For that reason, I consider the concept of experience derived from the German thinker, Wilhelm Dilthey (1833-1911). His concept of experience is Erlebnis. In German Erlebnis is 
contrasted to Erfahrung, while English uses experience for both. The latter has the sense as the actual observation of facts or events, considered as a source of knowledge. Erlebnis corresponds to the fact of being consciously the subject of a state or condition, or of being consciously affected by an event. Dilthey frequently and emphatically used Erlebnis because he wanted to distinguish his own empiricism from that concerned with sense data, by stressing personal, emotionally colored experience (in Rickman 1976).

Furthermore Dilthey describes that every particular experience refers to a self of which it is a part; it is structurally interrelated to other parts. Everything that pertains to mind is interrelated; interconnected. Furthermore Dilthey (1910) calls "systems interactions" of categories, such as part and whole with means and ends with inner and outer with past and future with individual and mankind with mental and physical, and with abstractions and physical objects. System of interactions assumes that the propositions into which the concepts are linked must not contain contradictions either within or among themselves. From that concept, Dilthey differentiate between "mere experience" and "an experience" (Turner 1986). He argues that:

"Looking back at the past in memory we see the connections between the parts of life in terms of the category of meaning. In the present wefeel the positive or negative value of the realities which feel it and, as we look towards the future, the category of purpose arises" (Dilthey 1910: 216).

Turner (1986:35) further elaborates that: "Mere experience is simply the passive endurance and acceptance of events. An experience, like a rock in a Zen sand garden, stands out from the evenness of passing hours and years". Throop (2003) also explains the Dilthey's distinction between the immediate living through of experience as a sequence of events (Erleben) and the retrospective attribution of meaning tied to the structuring of experience as a particular coherent unit or form (Erlebnis).

Furthermore, Dilthey argues that system of interactions as such is always complex, and we must remember that they work with abstractions. It leads Dilthey relates the interactions of abstractions to physical objects, that is the concept of expression. He argues that the individual in which it occurred takes part as a person in the system of interactions and what he expresses is the product of the person as a whole. To make them comprehensiblewe must in practice and treat them as emanation from physical objects. From that concept, experience is never truly completed until it is expressed, that is a physical manifestation of mental states. They are some 'forms' of expressions, the first is literary works, such as autobiographies, and letters, the second is performance works, such as drama (Dilthey 1910). 


\section{The Concep of Culture}

In consumer research, the concept of culture can be viewed as a cognitive model (Thompson and Arsel 2004). In their paper, Thompson and Arsel refer to D'Andrade's concept of cultural model (1990: 45). D'Andrade defines a cultural model as a cognitive schema that is intersubjectively shared by a cultural group. However, cultural models are not just in-the-head entities. Cultural models are also socially shared because they are objectified (see Miller 1998) through public discourses, material objects, and the design of the physical environment (Shore 1996). A cultural model shapes individuals' actions through conventionalized social practices, interactions with its material objectifications, and internalization of its discourses via cognitive structures and embodied habits. Besides that, the concept of culture can also be viewed as a transition that is moving from one cultural environment to another (Davies and Fitchett 2004).

Those concepts of culture relate to how they shape and accommodate a new discourse from social to individual and from one environment to another in "a one-way process". In short, the gap of "a two-way process" such as interaction between social and individual; and interaction between the environments to another still remain. For that reason, in this paper I argue that the concept of culture can also be viewed as revitalization. Clemmer (1969) concludes that revitalization is a conflict between cultural change and resistance; between adoption and maintaining. It means how the members of a society respond to specific situations in terms of those beliefs or values.

\section{Case}

The Slank is a pop-rock group band in Indonesia, which was formed on 26 December 1983 in Jakarta. The word "Slank" is derived from "Slengean", meaning straightforward, guileless, just the way they are. Its well known slogan is peace, which is applied universally, such as in politics, environment, and love. In 1993 two of five its group members, Bimbim and Kaka, used to be drugs consumers. Because of that, image of the Slank was unfortunately going bad. In 1995 with the assistance of Bunda -mother of Bimbim- Bimbim and Kaka totally stopped to consume drugs. The group band initiatively lunched many albums to convey how bad if they consume drugs, and to declare that everybody, especially to its community, to stay away from drugs. In 2000 the Slank lunched PLUR (Peace, Love, Unity, and Respect) slogan. The Slank says that its slogan is not only peace, but also love of self and others, unity of brotherhood, and respect of self and others. For Slank, disseminating PLUR means disseminates "virus," that is 'a good virus.'

The Slankers is a community who adores the Slank. Its members are around 2 millions in Indonesia spread across regions, they named as their region, such as Jakarta Slankers, and 
Surabaya Slankers. In Jakarta, Slankers usually hang out in the Slank's base camp.

For Slankers, the presence of the Slank is not just on a stage performance, but also in its imagination, it means, the Slank is not just a physical posture, but also an image. We argue that Slankers not just experience the Slank in "the realm of physical", but also in "the realm of imagination". Its imaginative experience is expressed in "Kans" media, that is a printed media of Slank and Slankers sold in Slankers' shops.

\section{Research Pradigm}

Consumer behavior is a complex phenomenon and an eclectic field. The majority of published researches are done by marketing academics who vary greatly in their training, objectives, and methods (Peter and Olson 2002:9). As shown in Table 1, there are three major approaches to studying consumer behavior.
The interpretive approach is relatively new in the field and has become quite influential. It is based on theories and methods from cultural anthropology (Peter and Olson 2002:10). There are literature of consumer behavior and consumer research that are anthropologically based such as Mc Cracken's (1988), Sherry's (1995), and Elliott and Elliott (2003). The complexity and specificity of consumer phenomenon lead to variety of anthropological context, such as Economic Anthropology (Firth 2004), Business Anthropology (Jordan 2003), Tourism Anthropology (Bruner 2005), and Media Anthropology (Askew and Wilk 2002). Ethnography is 'the trade mark' research method from anthropology. As variety of anthropological context, there are various ethnography, such as autobiography ethnography (Hannabuss 2000), internet ethnography (Kozinets 2002), visual ethnography (Pink 2001), communication ethnography (SavilleTroike 2003), consumption ethnography (Schouten and McAlexander

Table 1. Approaches to the Study of Consumer Behavior

\begin{tabular}{|c|c|c|c|}
\hline Approaches & Core Disciplines & Primary Objectives & Primary Methods \\
\hline Interpretive & Cultural anthropology & $\begin{array}{l}\text { Understanding consumption } \\
\text { and its meanings }\end{array}$ & $\begin{array}{l}\text { Long interview } \\
\text { Focus groups }\end{array}$ \\
\hline Traditional & PsychologySociology & $\begin{array}{l}\text { Explain consumer decision } \\
\text { making and behavior }\end{array}$ & $\begin{array}{l}\text { Experiments } \\
\text { Surveys }\end{array}$ \\
\hline $\begin{array}{l}\text { Marketing } \\
\text { Science }\end{array}$ & EconomicsStatistics & $\begin{array}{l}\text { Predict consumer choice } \\
\text { and behavior }\end{array}$ & $\begin{array}{l}\text { Math-modeling } \\
\text { Simulation }\end{array}$ \\
\hline
\end{tabular}

Source: Peter and Olson (2002:10) 
1995), and market-oriented ethnography (Arnould and Wallendorf 1994).

\section{Ethnographic Revolution}

Denzin (1997) argues that history of ethnography has three phases: Realism phase [Market (1900-World War II) to Blatant (1900-1920)] that is an objective ethnography; Modernism/ high modernism phase [Monopoly (World War II-1960) to Voyeurism Repressed (1930-1960)] that is a Golden age; Postmodernism [Multinational (1960-present) to Transgressive (1960-present)] that is Blurred genres and Writing culture. Besides, Denzin (1997) refers to Vidich and Lyman (1994) that interpretive inquiry (including ethnography) is a revolutionary path, from the traditional period to the fifth moment; that is the present, defined and shaped by the crisis previously described.

From the concept of imagination, Casey (1991) argues that in imagination, a "leap" between two wholly disparate states may occur. Besides that, from the concept of experience, Dilthey (1910) argues that experience is a "systems of interactions" of categories. Furthermore, from the concept of culture, Clemmer (1969) underlines that revitalization is a conflict between cultural change and resistance; between adoption and maintaining. From those three underlying concepts, I consider that there are three points: 1 ) there are two conflicting categories that they are equally treated; 2) there is a "leap" between conflicting categories that they are togetherness treated; 3 ) there is interaction between conflicting categories that they are sequentially treated.

Those points lead me to argue that this research paradigm as a circularity point of view or "a two-way process" of ethnography rather than a revolutionary point of view or "a one-way process." I coin that "two-way process" of ethnography is the narrativedialogic ethnography. In this ethnography, opposed categories treat on an equal level, and make circular among those categories. It means that there are no phases that one category treats traditional or lower than that of the other, rather one category through circularity can influences the other.

\section{Dialogic}

Dialogic is to make tense, as well as to confront, relate, and interact some categories. More specifically, tension is to oppose among categories; confrontation is to assemble one category with the other; relation is to share different source from those opposed categories; and interaction is to compete similar source from those opposed categories. Therefore, dialogic contains a paradox.

My definition of dialogic is different from that of Bruner (2005). Dialogic for Bruner is not restricted to describing a two-way binary interchange but calls for attention to multiple languages, to plural voices, and to heterogeneity of speech acts, genres, and styles. Bruner pointed out the heterogeneity rather homogeneity. In my opinion, dialogic based on both heterogeneity -that is relation-, and ho- 
mogeneity-that is interaction(Wagner 1984).

Based on that definition, narrative-dialogic ethnography is different from that of Denzin's three phases of ethnography (1997). In narrative-dialogic ethnography there is dialogic between opposed categories, it includes between structuralism (or modernism) ethnography (Strauss 1963, 1973) and posstructuralism (or postmodernism) ethnography (Clifford 1988; Marcus 1998; Tyler 1986).

\section{Narrative}

Narrative is representation of events or series of events. Event is the key word here, though some people prefer the word action (Abbott 2002:12). Furthermore, Abbot states that the difference between events and their representation is the difference between story (sequence of events) and discourse (how the story is conveyed). I can make many other changes in the discourse and still deal with the same story, Abbott give example to us:

- When I woke up, I packed two loaded guns and ski mask, drove to the bank, robbed it, and was back in time for dinner.

- I was back in time for dinner, having robbed the bank to which I had driven with a ski mask and two loaded guns just after my nap.

- He loved that old familiar, yet always strangely new, sensation of being someone else inside his ski mask, a pistol in each hand, watch- ing the frightened teller count out a cool million. Nothing like it to wake a guy up. Nothing like it to give him a good appetite.

Representation in Abbot's word is not similar to that of Cartesianism. Cartesianism is the distinction between mind and body and the assumption that "reality" must be deduced and then rendered in mathematical terms (Zaner 1970). Two major metaphors of Cartesianism are the machine and the container. The machine is restricted by constraints taking the form of principles and laws. The container is dualism that proposed separation of the mental and the physical worlds (Thompson et al. 1989).

In this paper, narrative composed of: 1) action, that is: a) story, which is actual chronological sequence of events. The basic question concerning story is "What happens next?"; b) discourse, which is story that the sequence depends on the narrator's sequence. It can be flash back, or flash forward; c) plot, which is the logical and causal structure of story. The basic question concerning plot is "Why does this happen?". 2) voice, that is: a) narration. It can be first-person narration, which is narrating me or narrating self, and reflector-mode narration, which is telling the others' experience. The basic question concerning voice is "Who speaks?"; b) focalization. Narrators can present events from somebody else's point of view. The basic question concerning focalization is "Who sees?"(Jahn 2005). 
Gadjah Mada International Journal of Business, September - December 2007, Vol. 9, No. 3

Several concepts of narrative are also proposed by Bruner (1986), Crandall and Brown (2003), and Turner (2003). They argue that if someone tells a story, what he or she tells is a story not a discourse. In this paper, I follow both narrative meaning. If I apply "story", it means one discourse, narration and certain focalization concerning one event, but if I apply "narrative", there are two meanings, first, it is a theory of narrative -that includes both action and voice-; second, they are many possibilities of discourses, narrations, and focalizations concerning one event (Gallie 1964). In this matter, if some one telling or retelling into a discourse, it means he or she constructs a pattern, it is a sequence of events (that is a story) from many possibilities of sequences (that is a narrative) (Holloway 1979).

\section{Narrative-Dialogic Ethnography}

The narrative-dialogic ethnography is the discourse of ethnographer to make tense, as well as to confront, relate, and interact some categories and accommodate possibilities of sequences of opposed categories. I consider those possibilities of sequence as circularity rather than revolutionary. The ethnographer's discourse is his or her choice from many possibilities of sequences. In this matter ethnographer makes a construction. That is a theory that is not only interrelated constructs (Creswell 1994) or interrelated concepts and propositions (Pelto 1970), but also a narrative-dialogic.
The discourse is not only the way of telling, and writing, but also the way of seeing and thinking. In this matter, I argue that the narrative-dialogic ethnography is a research paradigm, that is composed of (Guba and Lincoln 1994):

- Ontology: to view reality composed of tension, confrontation, relation, and interaction among categories, and finally becomes construction.

- Epistemology: to treat between categories as the narrative-dialogic.

- Methodology: to make tense, confront, relate, and interact among categories, and accommodate some possibilities of sequences from opposed categories. If one ethnographer's choices are possible, therefore it becomes a construction, that is an ethnographer's theory.

There are two characteristics of the narrative-dialogic ethnography. First, there is a narrative-dialogic between an expressive data (which is an experience phenomenon) and descriptive data (which is a knowledge description). It is a matter of data. On one side, expressive data is physical manifestation of mental states; those are experiences (Dilthey 1910). Rickman elaborates that:

"Complexstructurescan, andshould, be analyzed so as to reveal the elements they consist of but, if we begin with these, we cannot easily recapture the richness of experience which gives human life its distinctive qualities. For this reason Dilthey advocated and illustrated in his own work 
the use of autobiographies, literary works, letters, and diaries as suitable material for research" (Rickman 1976: 7).

Expressive data are written material related (Dilthey 1910) or mediated experience related (Giddens 1991). In this written material, hermeneutic research emphasizes an understanding of a text that always reflects a fusion of horizons between the interpreters' frame of reference and the texts being interpreted (Arnold and Fischer 1994; Gadamer 1993; Holbrook and O'Shaughnessy 1988; Thompson 1997; Thompson et al. 1994).

On the other side, descriptive data are cognitive based; those are knowledge (Spradley 1980). In this matter, I argue that the knowledge is an every member's knowledge toward his or her society rather people's knowledge as argued by Spradley and Curdy (1975). My argument relies on Marcus (1998) and Geertz (2000) that: "Social spaces whose edges are unfixed, irregular, and difficult to locate. We are living in the midst of an enormous collage, in the grand assemblage of juxtaposed difference" (Geertz 2000:85-86). In the narrative-dialogic ethnography, expressive data is opposed to descriptive data. The former is both physically and actively based. In Giddens (1991) words, the narrative of the self is made explicit, which the individual can ask: "What do I want for myself?". That is a narrative therapy (Payne 2000). The latter is both cognitively and passively based. In
Spradley (1980) words, there are descriptive questions that ethnographers can ask to their informants, one of those is: "Can you describe in detail all the events?".

One example of a pair of data, expressive data and descriptive data which subsequently appear as follows: "At thatmomentmy friends and I will go to take a tour to the recreational place, but the tour must pass my enemy's school. My friends and I always fight them. Because of that, one of my friends has an idea to rise up the Slank's flag if we pass my enemy's school. We agree on that. At that moment we pass my enemy at their school, one of my friends rise up the Slank's flag. Surprisingly, they just expressionless to see us, they did not throwtous with stones as theydid, then they follow us to make a peace's sign by their fingers. We can pass them safely because of the Slank's flag. Thanks to Slank, you are really to be a virus of peace in Indonesia". One of Slankers said to me: "In our journey to the Slank's concert I always rise up the Slank's flag. At that moment I feel glad. I believe that the others people know that the day of Slank'sconcert. Ithinkthat the Slank's flag is the sign for Slank's concert".

That expressive data appears in a Slank's newspaper, a communication media between Slankers and Slank. The descriptive data is obtained from my interview with one of Slankers. This ethnography does narrative-dialogic between those types of data. There 
are possibilities of sequences, such as expressive data-descriptive data, descriptive data-expressive data, expressive data-descriptive data-expressive data, and descriptive data-expressive data-descriptive data. Every possibility of sequences of those data leads me to make a different construction. Back to the above data, I do narrative-dialogic that start from expressive datadescriptive data-expressive data. From that narrative-dialogic, my construction is that Slankers construct a new construction of the meaning of Slank's flag.

The second characteristic of the narative-dialogic ethnography, that there is a narrative-dialogic between an interpretation and reflexivity. It is a matter of epistemology. The narrativedialogic ethnography treats an equal epistemology between ethnographer and his or her object (Soysa12001). On one side, interpretation is the method of coming to know the objects of this world of mind (Rickman 1976). It contains the relations of "inner to outer" (Dilthey 1910). According to Dilthey, in interpretation subject objectifies the objects. It is the way to reduce complexity and abstractions. Besides, it is also the way to reduce chaos (Geertz 1973) and confusion (Mehan and Wood 1975). On the other side, reflexivity means a turning back on oneself; a process of self-reference, in which boundaries between subject and object disappear, the one becomes the other (Davies 1999; G.H. Mead 1934; Scholte 1969). According to G.H.Mead
(1934), other profoundly influences our personal experience as it enters our awareness in the reflective act. Reflexivity contains the relations of "outer to inner". It is the way to open the self for others, so it also contains risks, dangers, and anxiety (Giddens 1991: $91,43)$. During interview with his or her informants, ethnographer does reflexive interview (Denzin 2001). According to Frijda (1986:187), reflexivity has two conditions; first, it is a transformation of awareness and the creation of subjectivity. The "me" who does the becoming aware becomes part of awareness, rather than merely being its condition or theoretical point of reference. "I know that I am perceiving $X$ " takes place of " There is X"; second, it appears to consist of discrete feels.

One example of a pair of interpretation and reflexivity subsequently appear as follows:

"I adore the Slank- the group band care to its fans. I have known the Slankfor two and a halfyears. Idonot why I obsessed to the Slank. The Slank also appears in my dream."

That is Istiqomah's expressive data. In her written story, she interprets that the Slank take care of their fans. Besides, she is to be a reflexive actor that she does not know why she obsessed to the Slank. In my side, as an ethnographer, I also interpret expressive data. Istiqomah is obsessed to the Slank, it leads her to dream the Slank. Before I read Istiqomah's story, on May 10, 2005, I was dreaming a mem- 
ber of Slank, his name is Kaka -he is the band vocalist-. To be honest, I did not know why I was dreaming the Slank, and especially Kaka. I realize that I need to go to the Slank's base camp because I did not go to that place almost two weeks. After I read Istiqomah's story, directly I said that I also can dream the Slank. That is my reflexivity.

In the narrative-dialogic ethnography, ethnographer conducts four roles. First, ethnographer interprets expression to the objects. Second, ethnographer reflects expression from the objects. There are possibilities of sequences, such as interpretive-reflexivity, reflexivity-interpretive, interpretive-reflexivity-interpretive, and reflexivity-interpretive-reflexivity. Third, the ethnographer's self make confession regarding what he or she experiences toward object's expression. Four, ethnographer constructs a sequence of events composed of narrative-dialogic.

In the narrative-dialogic ethnography, the ethnographer's self is presenting a voice rather than personal silence as argued by Geertz's "The Interpretations of Cultures"(1973). The narrative-dialogic ethnography is a narration-based ethnography in which the presence of the ethnographer is acknowledged (Stoler 1999:700). In this matter, the ethnographer's voice is not the egos. The ego, not a self, would be a self only by becoming reflexive, that is to say, acting toward or on itself (G.H. Mead 1934). In G.H. Mead words, the voice of ethnographer is a self indication of a moving communicative process in which the individual notes things, assesses them, gives them a meaning, and decides to act on the basis of the meaning. Besides, the ethnographer's voice is a narration of the narrator (Clifford,1986: 12; Maanen 1988).

The narrative-dialogic ethnography is categorized as a Being-Here ethnography (Geertz 1988). Geertz opposes a Being-Here ethnography with a Being-There ethnography, as follows: "Being There is a postcard experience ("I've been to Katmandu, have you?"). It is being Here, a scholar among scholars, that gets your anthropology read, published, reviewed, cited, taught" (Geertz 1988:130). Furthermore Geertz (1988:130) argues that Being Here ethnography is getting "their" lives into "our" works. It means there is an ethnographer's confession (Geertz 1988:145). That confession is realized through reflexivity (Geertz 1988:131).

The narrative-dialogic ethnography is also categorized as an Experimental ethnography (Marcus 1998). Marcus opposes a Discovery ethnography with an Experimental ethnography as follows: "Such a revision of ethnography changes the understanding of what ethnography is generally about. In the past, ethnography has been associated with discovery, meaning to describe specific groups of people who have not been treated before as "one tribe, one ethnographer". Opposingly, postmodernist ethnography derives its critical power and in- 
Gadjah Mada International Journal of Business, September - December 2007, Vol. 9, No. 3

sight from awareness or from reflexivity" (Marcus 1998:196-197).

The narrative-dialogic ethnography is also categorized as a reflexive ethnographic science (Aunger 2004). Aunger argues that: "The ethnographer cannot simply leave the reader to contribute the analysis, but has the obligation to interpret ethnographic material. As a consequence, I emphasize reflexivity as an aspect of analysis rather than presentation in the ethnographic document" (Aunger 2004:15, emphasis as original). The implication of reflexivity as an aspect of analysis is that the real issue isn't so much who is right and who is wrong -because the truth will always be contested- but whether any ethnography has value (Aunger 2004:3, emphasis as original). Furthermore Aunger argued that there is no single, hegemonic truth that an ethnographer can adopt, hence the great concern in the newer generations of ethnographers with explicitly representing ethnographic variation (Aunger 2004:5, emphasis as original).

\section{The Story of Imaginative Experience}

There are many stories of Slankers' imaginative experiences. Its imaginative experiences are expressed in "Kans" - a Slank and Slankers' printed media sold in Slankers shops-. From those stories, by categorizing, I find three-styles of imaginative experiences stories.
First, it is a Fadli's letter; he is a Slanker form East-Kalimantan.

"Tobehonest, when I was listening to the $8^{\text {th }}$ Slank's album, I felt eerie and remembered my best friend, the last Jana.

Here is the story:

Jana was a Slanker. After he graduated, he has got sick, terrible sick, so that his family took him on hospital. On the first day Imet him in hospital, I couldn't believe. His body was getting thin, he couldn't speak too; he just smiled. On the second day, Igave him a new Slank's album, the $8^{\text {th }}$ Slank's album, suddenly he looked bright and happy. He was enjoying listen that album. I looked some energy on his face. But it was a short moment, because in the next day, he passed away. Good-bye my best friend."

What Fadli told is his imaginative experience. It means that his imaginative experience is a story. In his letter, Fadli tells back his imaginative experience; it is his discourse of his story.

Second, it is a Marni's letter; she is a Slanker from West-Java.

"At the time I was writing this letter, I felt sad and I missed my father. He adored the Slank, because the songs are both romantic and poetic, also its dress just the way they were. My father passed away on November 10 , 2002. After that, I become adores to theSlank. WhenImiss myfather, then I will listen to Slanks's song, so my miss is fulfilled." 
In contrast to Fadli's imaginative experience, Marni writes her letter when she is experiencing her imaginative experiences; it is her story.

Third, it is a Wahyu's letter; he is a Slanker from East-Java.

"Ihave astory. Actuallyit is astoryof mybestfriend Andre, about his friend Kim. Andre is a Slanker. One day he asked to Kim to go together to see the Slank'sconcert. Kimhadneverknown and listened before about the Slank and its song. However, at the time he listened thesongs, suddenlyhelooked happyand dancedfollowtothesongs. Thenext day Kim told to others friend that he just watched the Slank's concert. His friend asked him about what the title of the songs that he heard. Surprisingly, Kim said that he didnot know what the title was. Spontaneously all were laughing. Since then, he still claimed himself as Slanker"

Wahyu writes the story of Kim, but Wahyu did not directly see what Kim did. In contrast to Fadli's and Marni's, Wahyu tells about the story; it is his discourse of other story.

From the three stories above, I argue that there are three-style of stories of imaginative experiences: (1) "tell back the story"; (2) "tell the story when it is happening"; (3) "tell about the story".

\section{The Realm}

To understand the realm of Slank and Slankers, I studied three the Slank's songs: "Mars of the Slankers", "Virus," "Blue," and one the Slankers' poem: "Responses from the Slankers", who written by Slanker.

\section{"Mars of the Slankers"}

This is the place who ones to enjoy This is the wrong place if you just make money

This is the place who ones with creativity

This is the place who ones to survive

This is the place not for lazy people

This is the place for hard worker

This the place not for the spoiled

Less work but many take

Works...Let'sgo...

"Virus"

Idon'twant to be a Satan to scareyou I don't want to be a devil to mislead you

What I want you to try to know me

What I want you learn to love me

Honestly...the way we were

I don't need to be a fire to burn your heart

I don't need to be a spine to hurt you

What I know is I try open

What Iknowis deliberately always to talk

Honestly...the way we were

I can be a virus to influence you

"Blue"

Loose my memory to the past

Breaking the time line 
Gadjah Mada International Journal of Business, September - December 2007, Vol. 9, No. 3

I open my mind flying far away

Breaking my fear and hesitate

Blue ....I miss you.

Blue ... I remember you.

Never loose my last memories...

Filling my mind...

To complete all my behavior...

"Responses from the Slankers"

We are going to the Slank's base camp not to be lazy

We are going there because you are my family

We are going there to look your daily activity

The real Slankers don't want to be lazy
The Slankers always support you The Slankers don't want to buy your pirated album

Not adoring so that not loving Pleaseletus knowyoumoreclosely

If you fall

We will up you

You can't die

Your song is our voice

Our soul is still red and white

We come to look our family that is the Slankers

We come to look our Bunda that is the mother of the Slankers

We come to look our home

In our heart has the peace virus

In our heart has the love

In our heart has the Slank

Figure 1. The Concept of Imaginative Experience

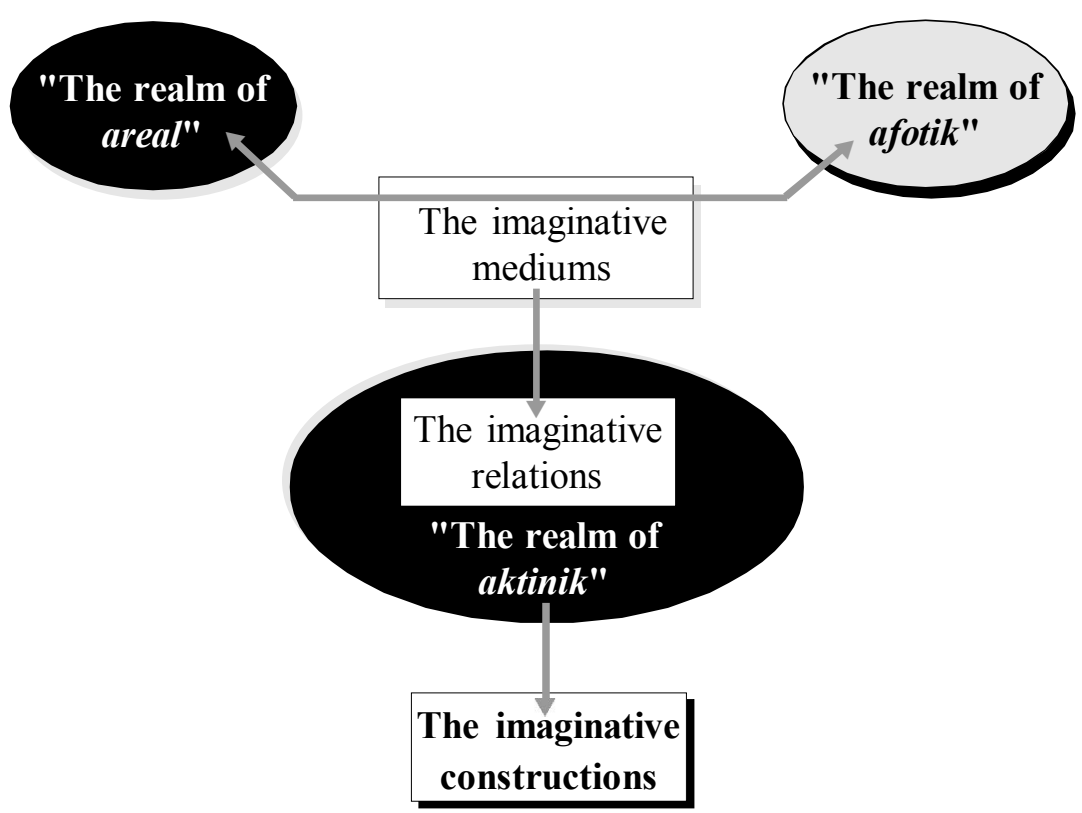


I interpret those songs and poem as three unique categories, each of those is: 1) "Mars of the Slankers" is "the realm of areal" - namely the category of "the realm of physical". The lyrics describe a place to make interpersonal relationship, daily activity, working hard. This realm contains a presence of people. 2) "Virus" is "the realm of afotik"- namely the category of "the realm of image". The lyrics convey a non-physical posture, 'a good Satan', 'a good devil', a virus. This realm contains a presence of images. 3) "Blue" is "the realm of aktinik"namely the category of "the realm of imagination". The lyrics convey relationship between the Slankers as the subject (act of consciousness) and the Slank as an object of consciousness. This realm contains a presence both of imagining subject and imagined object.

In the beginning, there is narrative-dialogic between "the realm of areal" and "the realm of afotik" synthesized by the imaginative mediums. That narrative-dialogic activates the imaginative relations in "the realm of aktinik." At the end, those imaginative relations construct the imaginative constructions. Such concept is called the concept of imaginative experience, as depicted in Figure 1.

\section{The Imaginative Mediums}

As Dilthey argues, Slankers express their experiences on many expressions; one of them is the typography on their T-shirt. At the time I watched Slanker wearing a black Tshirt pictured with the logo of the Slank in front of it with one sentence in the back. Such T-shirts are sold in the Slankers's stores that sell merchandises of the Slank and Slankers near the Slank's base camp. The sentence is: "However it is, I have the "God"".

I interpret it as both denotative meaning and as narrative meaning. Denotative meaning is absoluteness of the God's existence, that every one indeed has the God. Another interpretation is narrative meaning. I interpret the sentence as two sequential events. "However it is" is the first event, then "I have the "God"" is the second event. For me, "however it is" is "the realm areal" of the Slankers. In the "I have the "God"", I carefully pay attention on the "God" with apostrophe on that sentence. I relate that with synthesis that the essence of the concept of imagination. I interpret that Slankers synthesize the Slank image with the God image. It leads me to say that "I have the "God"" is "the realm of afotik". In turn, it leads me to state that there is imaginative medium that assembles "the realm of areal" with "the realm of afotik", and then it can activate "the realm of aktinik". Imaginative mediums could take any form, as I found in this study, there are many kinds of imaginative medium, such as a sentence on that T-shirt, song, specific number, signature, information on video clip, even self. I categorize four narrative-dialogic of imaginative medium, as follows. 
Gadjah Mada International Journal of Business, September - December 2007, Vol. 9, No. 3

First, imaginative medium rises 'in the middle of' and then assembles "the realm of areal" and "the realm of afotik," as Wawan's story:

"I run my own small business. One reason is that I seriously collect Slank's merchandise, so that I take mybusiness to make money as fast as I can, so I can buy another Slank's merchandise. At thatmoment, Iunintentionally founded information on one piece of pamphlet regarding the Slank's Jamboree on next month. I registered directly to be a member of that Jamboree, but I did not consider that my capital loose. After registration Ireally haveno business, but it is ok because the most important I can joint with Slank, took photographs and its signature on that Jamboree. I believe that I would rather loose my capital than I can't get my golden moment."

That information on a piece of pamphlet assemble both "the realm of areal" -namely uncertainty of getting a job- and "the realm of afotik" -namely certainty of presence of the Slank image.

Second, imaginative medium rises simultaneously with "the realm of areal" then assembles with "the realm of afotik", as Adi's story:

\section{Adi tells his first story:}

"I complain to the staff of the Slank [SlankandSlankers called "theFairy Rescuer" or "FR"]. On one of its performances, there was a Slanker who went to the stage and shookhand with one member of the band and
"FR" directly hit that Slanker. Ihope that event won't happen anymore."

He continuous his story: "Idid apologize, because Imade bad image to the "FR". At thatmoment, I actuallyfounded a nameless newspaper, and I read information regarding that event. I should never trust on $i t$, because I do believe that "FR" never did likewritten on it. SinceItold thefirststoryIcouldn'tsleepwelland regretful. Once again I do apologize to the Slankers in Indonesia, especially the "FR." Ipromisenot to do it anymore. I hope there is wisdom. PLUR."

That information on one piece of nameless newspaper rises simultaneously with "the realm of areal" -namely uncertainty of informationthen assembles with "the realm of afotik" — namely certainty of presence of the Slank image.

Third, imaginative medium rises simultaneously with "the realm of afotik" then assembles with "the realm of areal", as Yusuf's story:

"I have adored Slank since 1994. I always hunt any kind of Slank's merchandise. My dream was when I got married some day, I want to invite Slank. UnfortunatelyIcouldn'tmake it. My next dream is when I have a baby I will name my baby with the Slank's personnel name. My dream comestrue. Inamed mybaby: "BIMO ADRI AZZUARY”. It stands for:

$\begin{array}{ll}B I M O & : \text { Bimbim's real name } \\ A D & : \text { Abdee } \\ R & : \text { Ridho }\end{array}$


Ardianto-Imaginative Experience

\section{I $\quad:$ Ivan \\ AZZUARY : Bimbim's daughter. \\ The real name is Mezzaluna Azzuary, and her nick name is Una."}

That Yusuf's imaginative medium rises simultaneously with "the realm of afotik"-namely always present (the Slank always present in his dream)then assembles with "the realm of areal" —namely never present (the Slank never present in Yusuf's marriage).

Four, imaginative medium rises after "the realm of afotik" experienced then assembles with "the realm of areal”, as Donk's story:

"One day, Una just arrived from her school and tookherfather to go somewhere. Here is their conversation:

Una: Dad, is it true that Indonesia is a poor country?

Father: Please, do not talkloudly, we are ashamed for that!!!

Una: Why we should be ashamed?

Father: Our hero will get up from their grave. We should be ashamed for that...

Una: Could the dead body get up, dad?

Father: ????"

Una -Bimbim's daughter nameis also one of the Slanks's song titles which tells whether Bimbim's family can grow up Una in Indonesia. The lyric of that song is as follows:

"Indonesianization of Una"

Reny Please I need to talk to you About the future of my life
About our Mezzaluna

Reny please I want to know

The school's fee

When we are getting sick, how much do we pay doctor and medicine?

Can we be growing up Una in this country?

Oh Reny do you sure?

Human beingjustbecomes un human And the truth just become a commodity

Can we be protecting Una in this country?

Reny please do not always follow

Going to buytoys in Toy Story, and to eat in Mc Donald

But going to teach her how to play with traditional toys and to eat in traditional canteen

Will we open her mind in this country?

Will we bestrongtoIndonesianization of Una in this country?

That story rises because "the realm of afotik" is experienced - namely "wealthy" (Bimbim's image that give various instructions to their daughter) and then assembles "the realm of areal" - namely "poorly" ( Donk's everyday life).

Five, imaginative medium rises after "the realm of areal" is experienced and then assembles with "the realm of afotik", as Pipit's story:

"I have already finished my middle school exam. At that time, the result was bad, so my mother blamed me. I 
Gadjah Mada International Journal of Business, September - December 2007, Vol. 9, No. 3

cried, and then my friends tried to cheer me up. I stopped crying, but I was still sad. Then I hang out with my friend. At that timeanewspaperseller gave me the Kans-the Slank's newspaper-, in which I have tried to read for so long. I felt better and happy. I didn't care about my exam's result and my Kans' debt [Kans' costs around 1 dollar US7 because my mother just gave me money to go home. Ha...ha...ha...it'sok, because KanS can make me fell better and happy."

After Pipit experienced "the realm of areal"-namely sadness- and then the KanS rises together with "the realm of afotik" - namely happiness.

Six, imaginative medium rises because "the realm of areal" is experienced and then assembles with "the realm of afotik", as Agus's story:

"I have a younger brother; his name is Yudi a nine-year old. He is also a Slanker. One day, we went to the market, unsurprisingly we saw one cassette and CD shop that sold many pirated albums including Slank's album. I looked to Slank's album, suddenly my brother held my arm and said: "WeareSlankers, sodon'tlook any Slank's pirated albums, because Slank warns us to stay away from pirated album". I was both shocked andproudofhim. Heis influenced by Slank's virus apparently. I hope Slankers could help themselves to stay away from Slank's pirated album. PLUR."
Because pirated album is always available in the "realm of areal", then Agus looked that album, at that time, his younger brother (as his imaginative medium) rises and then assembles with "the realm of afotik"- namely the Slank's image that always convey to stay away from pirated album.

Seventh, imaginative medium rises because "the realm of afotik" is experienced and then assembles with "the realm of areal", as Budy's story:

"In the Slank's clip video "I Miss $U$ but I Hate U", there is a story of two Slankers who want to see its idol, the Slank. It is written in their diary that on June 11 Slank will perform in the slank's base camp. On that day they are going to the Slank's base camp to see its idol, but there is not alive as they want to. They are disappointed, and write to its diary that on July 11 the Slank's performance will be alive on that. Soon, that story will become a trigger for all Slankers that on July 11 Slankers crowd the Slank's base camp, but actually there is no Slank's performance."

Because the Slank's image conveys that the Slank and Slankers will meet in their base camp in "the realm of afotik," but not on the specific date, at that time the imaginative medium which the specific date that is created by Slankers - rises and then assembles with "the realm of areal."

From those stories, I make "internal inferential" conclusion based on the narrative-dialogic that there are 
four narrative-dialogics of imaginative mediums between "the realm of areal" and "the realm of afotik", that is how imaginative medium is conveyed. First, imaginative medium rises 'in the middle of' and then assembles both "the realm of areal" and "the realm of afotik". Second, imaginative medium rises simultaneously with one "realm" and then assembles with the other "realm". Third, imaginative medium rises after one "realm" is experienced and then assembles with the other "realm." Four, imaginative medium rises because one "realm" is experienced and then assembles with the other "realm".

\section{The Imaginative Relations}

The imaginative relation is a subject-object relationship in "the realm of aktinik". There are many Slankers' stories which describe the imaginative relations.

First, "the realm of aktinik" fused in "the realm of areal", as Andi's story:

"I promise to myself to be a real Slanker in the rest of my life since in themiddleschool. Slankhadchanged mylife from 'easy' life to really make a peace. I promised to my self that when Idie, mybody would becovered with theflag of Slank. Amen. Nowmy son is 4 years old. He loves to sing "Virus" and "Mars of the Slankers". My family is also Slankers. Slank is my soul, and Slankers is my spirit. Wherever Ilive, Slank's virus grows. Nowadays, around myneighborhood
I am spreading Slank's virus, until to have around 50 Slankers. I always tell about peace to them. Peace never dies. Icannottolerateifanybodydoes thing bad to Slank and Slankers. Iam not a hero, but if anybodydoes harmful things to Slank and Slankers in front of my eyes, I die for it. Swear! Peaceforall Indonesian's Slankers.'

In that story, Andi does not separate the two "realm". For him, the imaginative relation in "the realm of afotik" is experienced as well as in "the realm of areal."

Second, "the realm of aktinik" is separated from "the realm of areal", as Ulfi's story:

"I am a Slanker. I am absolutely prohibited tosee the concertofSlank, because Iam a student of a pesantren [school of Koranic studies for childrenandyoung people, most of whom areboarders]. Nevertheless, Icollect many of Slank's collections. I just make correspondencewithmyfriends via mail to collect those collections. In my school, we make a creativity project every year, and of course I make an art project of Slank's, such as T-shirts. I want to know whether Slank has pins, because I wear a veil. I want to have some Slank's photographs. Can I?"

In that story, Ulfi separate the two "realms". For her, the imaginative relation in "the realm of afotik", is not experienced in "the realm of areal."

Third, "the realm of aktinik" goes through narrative-dialogic with "the 
Gadjah Mada International Journal of Business, September - December 2007, Vol. 9, No. 3

realm of areal". The sequence is from "the realm of areal" to "the realm of aktinik", as Feri's story:

"Iwasahighschool'sstudent. Atthat time there was a campaign to select a school's student leader, and I was one of the candidates. Each candidate made posters. On my poster I stated that the Slank is my idol. As I gave my speech, surprisingly all of my friends supported me. I was honored. Butthen, theresultresembled to that of Slank's competition. In several competitions, Slankisnotchosen as the winner. I failed to be a leader, instead I was chosen as a treasurer. But it's ok. The more important thing is that I was really happy. I am proud to be a Slanker."

Four, "the realm of aktinik" goes through narrative-dialogics with "the realm of areal". The sequence is from "the realm of aktinik" to "the realm of areal," as Yos' story:

"On 29 March 2003, 3 p.m., our mountain hiking started in a rainy day. We insist to place the Slank's flagpole on the mountain's top. Our seventh-hours' journey is followed by the slanks's song: "\#1". Because of it was wet and slippery, we frequently slipped and lost of balance, but we faced them with patience and no regret. Finally, we reached the top, and placed the Slank's flagpole. It was proved that peace and lovecan never be separated."

From those stories, I make "internal inferential" conclusion based on the narrative-dialogic that there are three types of imaginative relations. First, "the realm of aktinik" fused in "the realm of areal". Second, "therealm ofaktinik" is separated from "therealm of areal." Third, "the realm of aktinik" goes through narrative-dialogic with "the realm of areal."

\section{The Imaginative Constructions}

I define that construction is based on distinction between story and narrative. In this matter, if someone is telling or retelling a discourse, it means that he or she constructs a pattern (Holloway 1979). It is a sequence of events -a story- from many possibilities of sequences -a narrative.

I analyze some Slankers' figures about Slank to understand the imaginative construction. In this paper I show two of some Slankers' figures, one of that, is what I call: "the Angels" as depicted on Figure 2. 


\section{Ardianto-Imaginative Experience}

Figure 2. "The Angels"

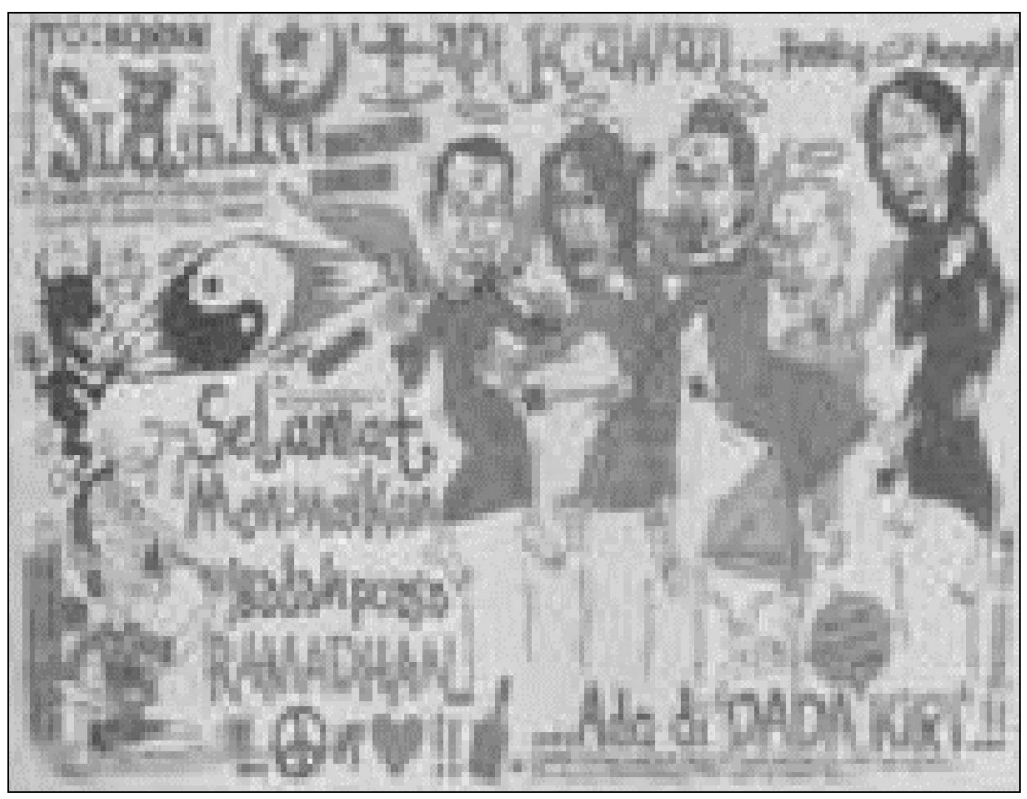

Source: Gibran, N., and F. Dhani (2004a).

\section{Figure 3. "Laudatory to God"}

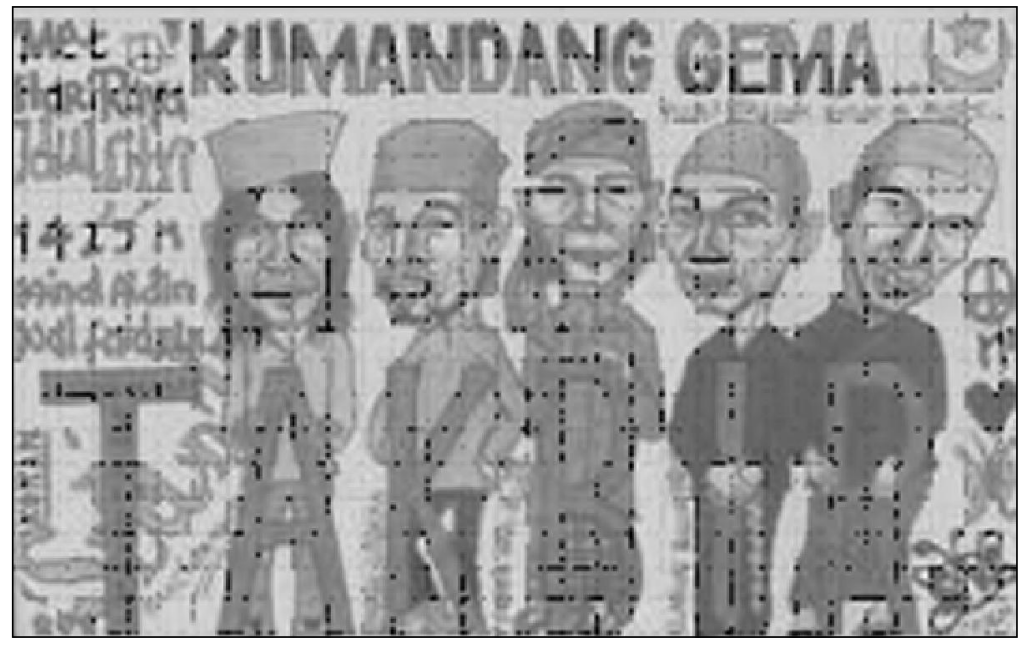

Source: Gibran, N., and F. Dhani (2004b). 
On that Figure 2, Slank as angels warns Slanker in the lower left corner to stay away from bad Satan. At that moment Slankers do a fasting ritual, and the bad Satan intrudes him to forget the fasting ritual and enjoy some delicious food and drink. I analyze that this is a narrative-dialogic between Slankers and the Slank as the angels to keep the Slankers to consistently do the sacred ritual. If we observe it in more detail, there is a single word of every Slank front name in his head that is $\mathrm{R}$ (Ridho), A (Abdee), $\mathrm{K}$ (Kaka), I (Ivan), B (Bimbim). If we read that sequence of words, it will become RAKIB, a name of angel in Islam. His duty is to record the good deeds of man.

On the Figure 3, I call a "laudatory to God" as depicted on Figure 3. Slank plays the role as 'the good man,' that every man wears a 'good clothes' ready to pray his God. Every man hold a single word of their first name, that is A (Abdee), K (Kaka), B (Bimbim), I (Ivan), and R (Ridho), and adds with $\mathrm{T}$ in front of that. The sequence words become TAKBIR, it is Islamic meaning of a laudatory to Allah.

From those figures, Slankers construct various constructions in which various sequential patterns are built from every single word of the Slank first name.

\section{Conclusion and Discussion}

This study finds that imaginative experience is the narrative-dialogic between "the realm of areal" and "the realm of afotik" synthesized by the imaginative mediums. That narrativedialogic activates the imaginative relations in "the realm of aktinik". At the end, those imaginative relations construct the imaginative constructions.

In this study, the community, who adores its idol, experiences the imaginative experience. For them, a presence of the idol is not just on a stage performance, but also in their imagination, it means, the idol is not just a physical posture, but is also an image. They do not experience the idol only in "the realm of areal"-namely the category of "the realm of physical"-, but also in "the realm of afotik" - namely the category of "the realm of image", in this matter "the realm of afotik" consists of the idol's image. The imaginative mediums activate imaginative relations in "the realm of aktinik" -namely the category of "the realm of imagination". Every member of that community constructs the imaginative relations. One type of imaginative relations that "the realm of aktinik" fused in "the realm of areal" describes that there is a strong relationship to peopleself-image. In that relation, self becomes an extended self(Belk 1988 and 1989). Finally, those imaginative relations construct imaginative constructions formed in personal story (Ahuvia 2005).

Those concepts of imaginative experiences implicate the concept of brand identity. In the imaginative experience concept, brand identity as an imaginative medium is the narrativedialogic between "the realm of areal" 
and "the realm of afotik". It is different from Keller's brand identity. For Keller, brand identity answers question of who you are (2003: 75). It is a narrative-dialogic based compared to description based. Besides, the imaginative experience concepts also add the concept of community. In community, people not only share essential resources that may be cognitive, emotional, or material in nature (McAlexander et al. 2002), and also not only share rituals and tradition conventionally (Muniz and O'Guinn 2001), but also construct its imaginative experience personally.
The concept of imaginative experience can benefit brand managers to build their brand. The "Imaginative Experience Management" (IEM) can accommodates company's experiencer (its consumers who experience the imaginative experience) who are involved in the company's products deeply and sustainable by managing the story of imaginative experience. Through its community, brand managers should accommodate their member constructions into a loyalty program, in which consumers' involvement can be managed.

\section{References}

Abbott H. P. 2002. The Cambridge Introduction to Narrative. New York, NY: Cambridge University Press.

Ahuvia, A. C. 2005. Beyond the extended self: Loved objects and consumers' identity narratives. Journal of Consumer Research 32 (June): 171-184.

Arnold, S., and E. Fischer. 1994. Hermeneutics and consumer research. Journal of Consumer Research 2 (June): 55-70.

Arnould, E. J., and M. Wallendorf. 1994. Market-oriented ethnography: Interpretation building and marketing strategy formulation. Journal of Marketing Research XXXI (November): 484-504.

Askew, K. and R. R. Wilk (ed.). The Anthropology of Media: A Reader. Malden, MA: Blackwell Publishers.

Aunger, R. 2004. Reflexive Ethnographic Science. Walnut Creek, CA: AltaMira Press.

Belk, R. W. 1989. Extended self and extending paradigmatic perspective. Journal of Consumer Research 16 (June): 129-132.

Belk, R. W. 1988. Possessions and the extended self. Journal of Consumer Research 15 (September): 139-168.

Bruner, E. M. 2005. Culture on Tour. Chicago: The University of Chicago Press.

Bruner, E. M. 1986. Ethnography as Narrative. In Turner.V.W. and Bruner E. M. (eds.), The Anthropology of Experience. Urbana and Chicago: University of Illinois Press. 
Gadjah Mada International Journal of Business, September - December 2007, Vol. 9, No. 3

Carù, A., and B. Cova. 2006. How to facilitate immersion in a consumption experience: Appropriation operations and service elements. Journal of Consumer Behavior 5 (February): 4-14.

Casey, E. 1991. Spirit and Soul -Essays in Philosophical Psychology, Dallas, Texas: Spring Publications.

Chan, K., and J. U. McNeal. 2006. Rural Chinese children as consumers: Consumption experience and information sourcing. Journal of Consumer Behavior 5 (May/June) (iss. 3): 182-193.

Chronis, A. 2005. Our byzantine heritage: Consumption of the past and its experiential benefits. Journal of Consumer Marketing 22: 213-222.

Clemmer, R. O. 1969. Truth, duty, and the revitalization of anthropologists: A new perspective on cultural change and resistance. In Dell Hymes (ed.) Reinventing Anthropology. New York, NY: Vintage Book.

Clifford, J. 1986. Introduction. In James Clifford and George E. Marcus (eds.), Writing Culture: The Poetics and Politics of Ethnography. Berkeley,CA: University of California Press.

Clifford, J. 1988. Predicament of Culture, Twentieth-Century Ethnography, Literature, and Art. Cambridge, MA: Harvard University Press.

Crandal, J. M., and M. H. Brown. 2003. The millenium waltz: A story in three-quarter time. In Clair R.P. (ed.). Expressions of Ethnography-Novel Approaches to Qualitative Methods. Albany, NY: State University of New York Press.

Creswell, J. W. 1994. Research Design, Qualitative and Quantitative Approaches. London: Sage Publications.

D’Andrade, R. 1990. Cultural cognition. In Poser M. I. (ed.), Foundations of Cognitive Science. Cambridge, MA: MIT Press.

Davies, A. and Fitchett. 2004. Crossing culture: A multi-method enquiry into consumer behavior and the experience of cultural transition. Journal of Consumer Behavior (3) (June) (iss. 4): 315-330.

Davies, C. A. 1999. Reflexive Ethnograph: A Guide to Researching Selves and Others. London: Routledge.

Denzin N. 1997. Interpretive Ethnography: Ethnographic Practices for the $21^{\text {st }}$ Century. London: Sage Publications.

Denzin N. 2001. The reflexive interview and a performative social science. Qualitative Research 1 (1). London: Sage Publications.

Dilthey, W. 1910. The construction of the historical world in the human studies. In Rickman H. P. (ed. 1976). Wilhelm Dilthey-Selected Writings. Cambridge, MA: Cambridge University Press,

Elliott, R., and N. J. Elliott. 2003. Using ethnography in strategic consumer research. Qualitative Market Research 6 (4): 215-223.

Firth, R. 2004. Themes in Economic Anthropology. London: Routledge.

Frijda, N. 1986. The Emotions. New York, NY: Cambridge University Press. 
Ardianto-Imaginative Experience

Gadamer, H. G. 1993. Truth and Method (2 ${ }^{\text {nd }}$ ed.). New York, NY: Continuum.

Gallie, W. B. 1964. Philosophy and the Historical Understanding. London: Chatto and Windus.

Geertz, C. 1973. The Interpretation of Cultures, Selected Essay. New York, NY: Basic Books Publishers.

Geertz, C. 1988. Works and Lives, The Anthropologist as Author. Oxford, UK: Polity Press and Basic Blackwell.

Geertz, C. 2000. Available Light-Anthropological Reflections on Philosophical Topics. Princeton, NJ: Princeton University Press.

Gibran, N., and F. Dhani. (2004a). Koran2an Slank (October)

Gibran, N., and F. Dhani. (2004b). Koran2an Slank (November)

Giddens, A. 1991. Modernity and SelfIdentity: Self and Society in the Late Modern Age. Stanford, CA: Stanford University Press.

Guba, E.G. and. Y. S. Lincoln. 1994. Competing paradigms in qualitative research. In Denzin N.K and Lincoln Y. S. (eds.), Handbook of Qualitative Research. London: Sage Publications.

Hannabuss, S. 2000. Being there: Ethnographic research and autobiography. Library Management 21: 99-106.

Holbrook, M. B. 2000. The millennial consumer in the texts of our times: Experience and entertainment. Journal of Macromarketing 20 (2) (December): 178-192.

Holbrook, M. B., and E. C. Hirschman. 1982. The experiential aspects of consumption: Consumer fantasy, feelings, and fun. Journal of Consumer Research 9 (February): 132-140.

Holbrook, M. B., and J. O'Shaughnessy. 1988. On the scientific status of consumer research and the need for an interpretive approach in studying consumer behavior. Journal of Consumer Research 15 (December): 398-402.

Holloway, J. 1979. Narrative and Structure: Exploratory essays. Cambridge, MA: Cambridge University Press.

Hoyer, W. D. and D. J. MacInnis. 1997. Consumer Behavior> Boston, MA: Houghton Mifflin Company.

Jahn, M. 2005. Narratology: A Guide to the Theory of Narrative. Köln, Germany: University of Cologne.

Jordan, A. T. 2003. Business Anthropology. Long Grove, IL: Waveland Press.

Keller, K. L. 2003. Strategic Brand Management: Building, Measuring, and Managing Brand Equity (2 ${ }^{\text {nd }}$ ed.). Upper Saddle River, NJ: Prentice Hall.

Kelly, R. F. 1987. Culture as commodity: The marketing of cultural objects and cultural experiences. Advances in Consumer Research XIV: 347-351.

Kozinets, R. 2002. The field behind the screen: Using netnography for marketing research. Journal of Marketing Research XXXIX (February): 61-72. 
Gadjah Mada International Journal of Business, September - December 2007, Vol. 9, No. 3

Maanen, J. V. 1988. Tales of the Field, On Writing Ethnography. Chicago, IL: The University of Chicago Press.

Marcus, G. E. 1998. Ethnography through Thick and Thin. Princeton, NJ: Princeton University Press.

Mariampolski, Hy. 2006. Ethnography for Marketers: A Guide to Consumer Immersion, London: Sage Publications.

Martin, B. A. S. 2004. Using the imagination: Consumer evoking and thematizing of the fantastic imaginary. Journal of Consumer Research 31 (June): 136-149.

McAlexander J. H., J. W. Schouten, and H. F. Koenig. 2002. Building brand community. Journal of Marketing 66 (January): 38-54.

McCracken, G. 1988. Culture and Consumption: New Approaches to The Symbolic Character of Consumer Goods and Activities. Bloomington, IN: Indiana University Press.

Mead, G. H. 1934. Mind, Self, and Society. Chicago, IL: University of Chicago Press.

Mehan, H., and H. Wood. 1975. The Reality of Ethnomethodology. Canada: John Wiley.

Miller, D. 1998. A Theory of Shopping. Ithaca, NY: Cornell University Press.

Moisio R., and E. J. Arnould. 2005. Extending the dramaturgical framework in marketing: Drama structure, drama interaction and drama content in shopping experiences. Journal of Consumer Behavior 4 (iss. 4): 246-256.

Molesworth, M. 2006. Real brands in imaginary worlds: investigating players' experiences of brand placement in digital games. Journal of Consumer Behavior. 5 (Jul/ Aug) (iss. 4): 355-367.

Moustakas, C. 1994. Phenomenological Research Methods. London: Sage Publications.

Muniz, A. M. Jr., and T. C. O'Guinn. 2001. Brand community. Journal of Consumer Research 27 (March): 412-432.

Payne, M. 2000. Narrative Therapy. London: Sage Publications.

Pelto, P. J. 1970. Anthropological Research: The Structure of Inquiry. New York, NY:Harper and Row.

Peter, P. J., and J. C. Olson. 2002. Consumer Behavior (6 ${ }^{\text {th }}$ ed.). New York, NY: Mc GrawHill.

Pink, S. 2001. Visual Ethnography: Images, Medium and Representation in Research. London: Sage Publications.

Rickman H. P. 1976. Introduction. In Rickman H.P. (ed.), Wilhelm Dilthey-Selected Writings. Cambridge, MA: Cambridge University Press.

Schmitt, B. H. 1999. Experiential Marketing. New York, NY: Free Press.

Scholte, B. 1969. Toward a reflexive and critical anthropology. In Hymes D. (ed.), Reinventing Anthropology. New York, NY: Vintage Books.

Schouten J. and J. McAlexander. 1995. Subcultures of consumption: An ethnography of the new bikers. Journal of Consumer Research 22 (June): 43-61. 
Ardianto-Imaginative Experience

Schiffman, L. G., and L. L. Kanuk. 2006. Consumer Behavior ( $9^{\text {th }}$ ed.). New York, NY: Prentice Hall.

Sherry, J. F. Jr. (ed.). 1995. Contemporary Marketing and Consumer Behavior - An Anthropological Source Book. London: Sage Publications.

Shore, B. 1996. Culture in Mind. New York, NY: Oxford University Press.

Soysal, L. 2001. Diversity of experience, experience of diversity. Cultural Dynamics 13 (1). London: Sage Publications.

Spradley, J. P. 1980. Participant Observation. New York, NY: Holt, Rinehart, and Winston.

Spradley, J.P., and D. McCurdy. 1975. Anthropology: The Cultural Perspective, Canada: John Wiley.

Stevens L., and P. MacLaran. 2005. Exploring the 'shopping imaginary': The dreamworld of women's magazines. Journal of Consumer Behavior 4 (4): 282-292.

Stoller, P. 1999. Back to the ethnographic future. Journal of Contemporary Ethnography 28 (6) (December).

Strauss, C. L. 1963. Structural Anthropology 1. London: Penguin Books.

Strauss, C. L. 1973. Structural Anthropology 2. London: Penguin Books.

Thompson, C. J, and Z. Arsel. 2004. The starbucks brandscape and consumers' (anticorporate) experiences of glocalization. Journal of Consumer Research 31 (3) (December): 631-643.

Thompson, C. J, H. R. Pollio, and Locander. 1994. The spoken and the unspoken: A hermeneutic approach to understanding the cultural viewpoints that underlie consumers' expressed meanings. Journal of Consumer Research 21 (3) (December): $432-451$

Thompson, C. J. 1997. Interpreting Consumers: A hermeneutical framework for deriving marketing insights from the texts of consumers' consumption stories. Journal of Marketing Research 34 (November): 438-455.

Thompson, C. J., W. B. Locander, and H. R. Pollio. 1989. Putting consumer experience back into consumer research: The philosophy and method of existential phenomenology. Journal of Consumer Research 16 (September): 133-146.

Throop, J. C. 2003. Articulating experience. Anthropological Theory 3 (February). London: Sage Publications.

Saville-Troike M. 2003. The Ethnography of Communication: An Introduction. Malden, MA: Blackwell Publishing.

Turner, P. K. 2003. Telling the story of birth. In Clair R.P. (ed.), Expressions of Ethnography-Novel Approaches to Qualitative Methods. Albany, NY: University of New York Press.

Turner, V. W. 1986. Dewey, Dilthey, and Drama: An essay in the anthropology of experience. In Turner V.W. and E. M. Bruner (eds.), The Anthropology of Experience, Chicago, IL: University of Illinois Press. 
Gadjah Mada International Journal of Business, September - December 2007, Vol. 9, No. 3

Tyler S. 1986. Post-modern ethnography: From document of the occult to occult document. In Clifford J., and G. E. Marcus (eds.). Writing Culture: The Poetics and Politics of Ethnography. Berkeley, CA: University of California Press.

Vidich, A., and S. Lyman. 1994. Qualitative methods: Their history in sociology and anthropology. In Denzin N. K., and Y. Lincoln. (eds.), The Handbook of Qualitative Research. Thousand Oaks, CA: Sage Publications.

Wagner, D. G. 1984. The Growth of Sociological Theories. London: Sage Publications.

Zaner, R. M. 1970. The Way of Phenomenology. New York, NY: Pegasus. 